\title{
Seismic reflection data in the Umbria Marche Region: limits and capabilities to unravel the subsurface structure in a seismically active area
}

\author{
Francesco Mirabella, Massimiliano R. Barchi and Andrea Lupattelli \\ Dipartimento di Scienze della Terra, Università degli Studi di Perugia, Italy
}

\begin{abstract}
Before seismic data were made available, the subsurface setting of the Umbria-Marche area was mainly derived from the extrapolation of surface data and from models resulting from analogies with other mountain chains around the world. During the ' 90 s industrial seismic data availability considerably increased, allowing the definition of new, previously unknown features. Beside the industrial seismic data availability, a deep crustal, near vertical seismic section trending E-W was acquired (CROP-03) across the Italian peninsula from the Tyrrhenian to the Adriatic coast. The subsurface data defined the compressional deformation style (thin- Vs thick- skinned) and the extensional deformation style. A set of east-dipping low-angle-normal faults, which dissect the previous compressional structures and which are the dominant features controlling the extension of the Apennines were recognised. The subsequent application of the seismic data interpretation to seismotectonic issues, defined in more detail the subsurface geometries of the active faults and the relationships between upper crust structure and seismicity.
\end{abstract}

Key words seismic reflection data - upper crust structure - deformation style

\section{Introduction}

The Umbria-Marche region comprises the Umbria-Marche Apennines, an arc-shaped fold-and-thrust belt, verging towards ENE, and the Umbria pre-Apennines (Bally et al., 1986), west of the Umbria-Marche Apennines (fig. 1a) where Miocene turbidites crop out, (see Barchi et al., 2001 for a recent review).

The Umbria-Marche Apennines are a mountain belt formed by two main groups of

Mailing address: Dr. Francesco Mirabella, Dipartimento Scienze della Terra, Università degli Studi di Perugia, P.zza Università 1, 06100 Perugia, Italy; e-mail: mirabell@unipg.it anticlines, the «Inner» and «Outer» Ridges of Scarsella (1951), separated by a large synclinorium (Matelica-Camerino synclinorium - MCsynclinorium, fig. 1a) and with wavelength of $15-20 \mathrm{~km}$. The compressional tectonics started in Middle Miocene in Western Umbria and migrated eastwards through time towards the Adriatic coast, where it is currently active. The compressional structures were later dissected by a set of NW-SE trending normal faults starting from late Pliocene - lower Pleistocene (e.g Lavecchia et al., 1994a) which extend both NW and SE of the study area (fig. 1b). Extensional tectonics is now active along the main ridge of the Apennines, as shown by both the historical and the instrumental seismicity (see Lavecchia et al., 1994a; Boschi et al., 2000; Barchi et al., 2006 for a review).

The schematic stratigraphy of the region (fig. 2) is composed of (bottom to top): i) Pale- 


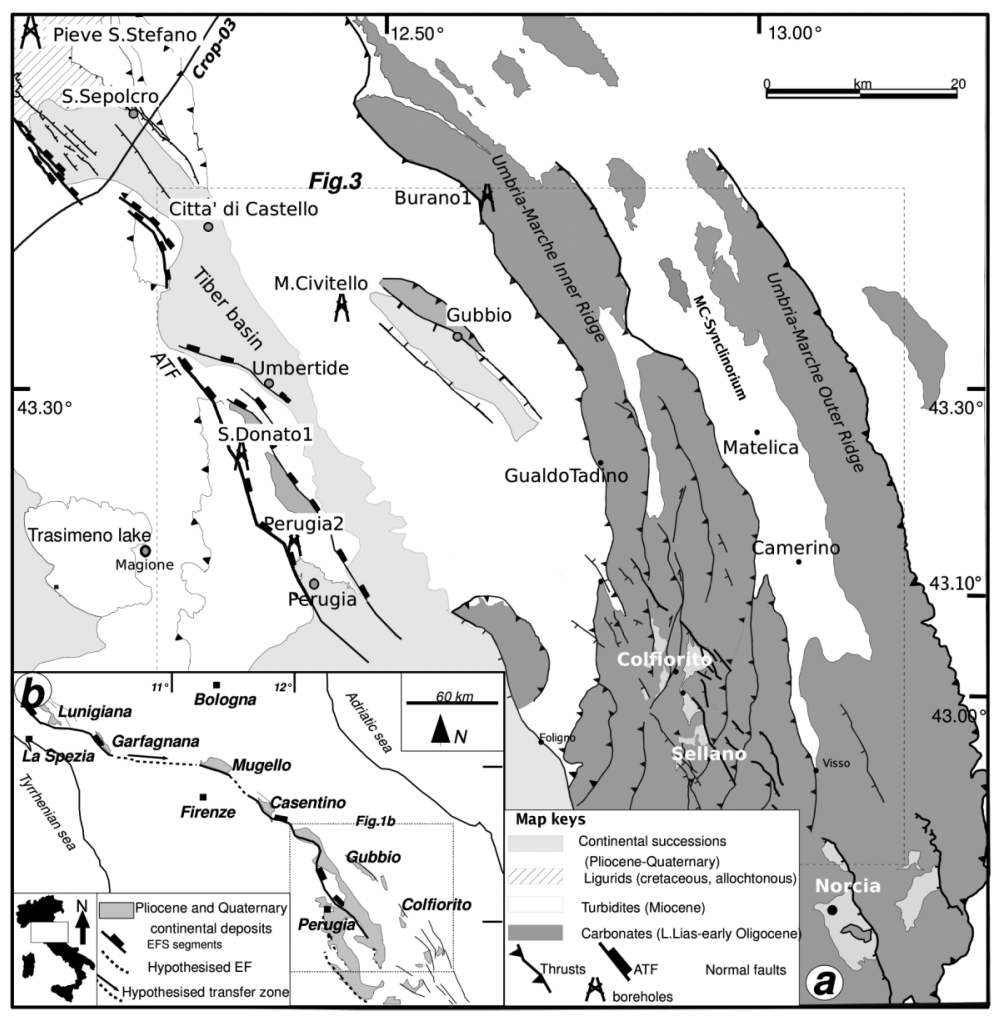

Fig. 1a,b. a) Geological sketch of the Umbria-Marche region. The region can be divided into two main sub-regions, the arcuate-shaped Umbria-Marche Apennines (Inner and Outer ridges, Scarsella, 1951) to the East and the Umbria-Marche pre-Apennines (Bally et al., 1986). On the figure, also the locations of the available boreholes and of the Crop-03 NVR seismic section are shown for further reference. b) North-western and south-eastern extension of the Quaternary normal faults and of the associated basins (redrawn after Boncio et al., 2000).

ozoic to Middle Triassic basement rocks; ii) Late Triassic evaporites (alternated anhydrites and dolomites - Anidriti di Burano fm, Martinis and Pieri, 1964); iii) a carbonatic multilayer (lower-Lias - early Oligocene) composed of carbonatic platform limestones (Calcare Massiccio fm) beneath basinal limestones and a preturbiditic sequence (early Oligocene-early Miocene) made of marly limestones; iv) a Miocene turbiditic sequence (Marnoso Arenacea fm, west of the Inner Ridge) made of sandstones and marls. Both the basement and the Anidriti di Burano fm never crop out in the belt and they were drilled by deep boreholes in the past years (Anelli et al., 1994) where the Anidriti di Burano were found to have a thick- ness of about $2 \mathrm{~km}$. In this paper we will refer to the Anidriti di Burano fm as «evaporites». As far as the basement is concerned, its upper part (about $2 \mathrm{~km}$ thick) is formed by a complex rock assemblage, consisting of phyllites from the Upper Paleozoic age. In some wells (e.g., Alessandra 1, Puglia 1, Bally et al., 1986; Patacca and Scandone, 2001), siliciclastic rocks (sandstones and slightly metamorphosed pelites) of the Permian and early Triassic have been found beneath the Verrucano Group (Middle Triassic). Other similar rocks (Upper Paleozoic/lower Triassic) to those drilled in the Umbria-Marche wells crop out in Tuscany (Lazzarotto et al., 2003). Here we refer to this rock assemblage as «top of the basement». Below 
these rocks the genuine crystalline basement was never reached by any drilling. Despite the lithological variability, these rocks possess a $\mathrm{Vp}$ between 4.8 and $5.2 \mathrm{~km} / \mathrm{s}$, a significantly lower value than that of the evaporites above $(\mathrm{Vp}>$ $6.0 \mathrm{~km} / \mathrm{s}$ ). This sharp decrease in $\mathrm{Vp}$ of the top of the basement rocks generates a characteristic group of high - amplitude reflections that can be followed in the seismic profiles (fig. 2). The thickness of the top of the basement is not well constrained. However, according to seismic refraction surveys (Ponziani et al., 1995; De Franco et al., 1998) it is at least $2 \mathrm{~km}$ thick, even though the wells have penetrated a maximum thickness of $1500 \mathrm{~m}$ (Anelli et al., 1994).

The surface geology of the Umbria-Marche region has been intensively investigated for about 150 years, producing regional studies which remain among the milestones of the Italian geology, anticipating some important concepts of the evolution of the thrust belts (e.g. Lotti, 1926; Merla, 1951). Despite this huge amount of data and observations, the subsurface setting remained poorly known until the ' 80 s. The pioneer subsurface reconstructions were based on few geophysical and seismological data and/or on analogies with other similar regions, where more information was available.

In the last 25 years, starting from the very influential paper by Bally et al. (1986), an increasing amount of seismic reflection data have been made available, giving a significant impulse to the studies about the structural style of the thrust and fold belt, even if contrasting interpretations are still proposed. In the same years, the quality and quantity of seismological data increased enormously, collected either by the National network of INGV (Chiarabba et al., 2005; Amato et al., 2006), or by local networks operating during earthquake sequences (e.g. at Gubbio in 1984, Haessler et al., 1988; and at Colfiorito in 1997, Amato et al., 1998), as well as by microseismicity surveys (Piccinini et al., 2003). At present, the Umbria-Marche region is a candidate to be a natural laboratory for the study of extensional earthquakes, where high resolution seismological data can be compared with surface and subsurface geology.

This paper reviews the contribution of seismic reflection profiles to the knowledge of the

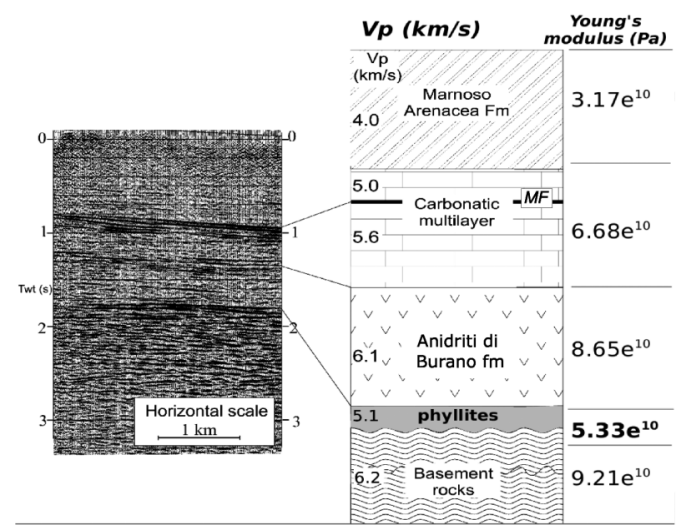

Fig. 2. Seismic stratigraphy of the Umbria-Marche region, also the $\mathrm{Vp}(\mathrm{km} / \mathrm{s})$ and Young's modulus $(\mathrm{Pa})$ values are reported. $\mathrm{MF}$ represents the Marne a $\mathrm{Fu}-$ coidi marl reflector (age: Aptian -Albian), a key horizon in the Umbria-Marche seismic stratigraphy. Phyllite indicates the complex low-velocity rock assemblage (see text for description) which seats at the top of the crystalline basement and which is characterised by high amplitude set of reflections which are very well imaged by the seismic sections.

subsurface structural setting of the UmbriaMarche region, where moderate earthquakes $(5<\mathrm{M}<6)$ occurred in the last 25 years, activating a complex system of SW-dipping normal faults, in the shallower portion of the upper crust (e.g. Ciaccio et al., 2005; Collettini et al., 2003; Chiaraluce et al., 2005). We will review and discuss the results of the interpretation of a grid of seismic sections (Barchi et al., 1999; Pauselli et al., 2002; Mirabella et al., 2004; Mirabella et al., 2008) (fig. 3a) and their contribution to the reconstruction of the subsurface geology, which provides independent information on: i) the style of deformation characterizing the compressional and extensional tectonics and their geometry and kinematics and ii) the rocks occurring at seismogenic depth.

\section{Seismic data in the Umbria-Marche Apennines}

The subsurface geology of the UmbriaMarche region was explored by the Italian Oil 
Company Agip (presently Eni SpA) in the 1980s through seismic lines and boreholes. The seismic reflection data have been progressively made available for scientific purposes bringing new information about the subsurface setting of the Umbria-Marche region. The acquisition depths of the seismic data are about 4-5 s twoway-time (twt), which correspond to about 12 $\mathrm{km}$ according to the average velocity field.

The location of the seismic data now available in the Umbria-Marche region is shown in fig. 3. The data-set presented in this review consists of 14 transversal seismic sections (S1S14), 8 longitudinal sections (S15-S22) and 4 boreholes. The location of the seismic profiles is not homogeneous. In the Umbria-Marche pre-Apennines, from Città di Castello to Perugia, there is quite a dense grid of seismic sections (sections S1 to S11), while in the Umbria-
Marche Apennines, from Perugia to Sellano only three seismic sections (S12, S13 and S14) are available.

Beside the data density, the data quality is not homogeneous, mainly depending on the combining effect of acquisition methods and outcropping lithologies. The sections S1 to S11 were acquired both by Vibroseis and Explosives. In this part of the Umbria-Marche region, the outcropping lithologies are mostly turbidites (Marnoso arenacea fm, e.g. Menichetti and Pialli, 1986) which allow a very good penetration of the seismic signal at depth. As a result, the subsurface structures are very well imaged to depths of about $4 \mathrm{~s}$ (twt) (see the westernmost parts of fig. 4a,b,c). On the other hand, when the outcropping lithologies are composed of the highly deformed carbonatic multilayer like in the Umbria-Marche Apennines and

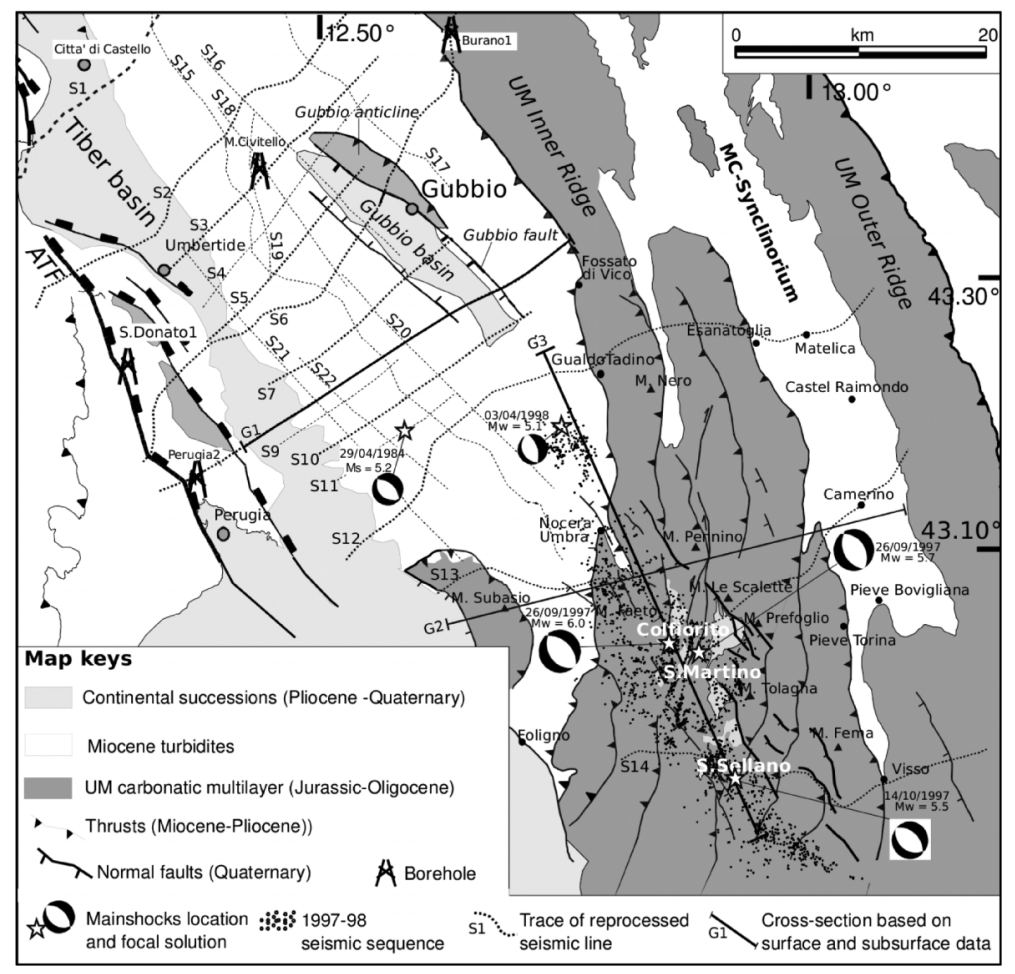

Fig. 3. Location of the available seismic reflection data and boreholes in the study area. On the figure also the locations of the 1997-98 seismic sequence and of the 1984 (Gubbio, Collettini et al., 2003) and 1997-98 (Umbria-Marche, Chiaraluce et al., 2003; Ciaccio et al., 2005) mainshocks are shown. 


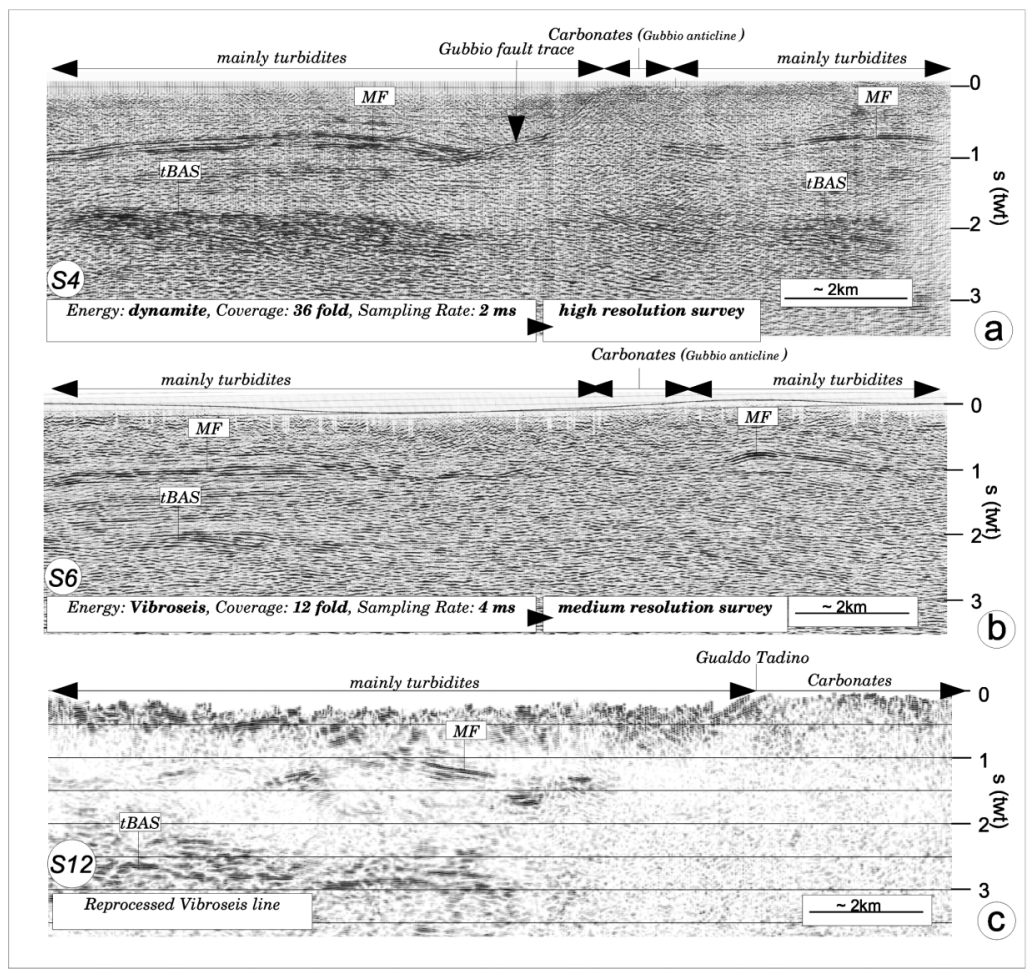

Fig. 4a,b. The control of geological complexity, outcropping lithologies and seismic data quality on the seismic resolution of the geological structures. a) Seismic line S4 (Mirabella et al., 2004, location in fig. 3). The line was acquired with explosives and shows the subsurface structures to a depth of 3s (twt); b) Seismic line S6, the line was acquired with Vibroseis; c) reprocessed S12 seismic line (Stucchi et al., 2006). The original data were acquired with Vibroseis. tBas refers to the top of the basement; MF refers to the Marne a Fucoidi fm, (see fig. 2). The three seismic reflection lines show the combining effect of acquisition technology and outcropping lithologies in the resolution of the data In the Umbria-Marche region. See text for details.

across the Gubbio anticline (see location in fig. 3 ), the seismic energy is absorbed and not well penetrating at depth. This is shown in fig. $4 a, b$ in which the sections (S4 and S6 in fig. 3 respectively) cross the Gubbio anticline. The two lines were acquired very close to each other, and the stratigraphy is the same. They cross turbidites in the western and eastern part and carbonates (Gubbio anticline) in the central part. The seismic section of fig. 4a was acquired with explosives while the section of fig. $4 \mathrm{~b}$ was acquired with Vibroseis. The section of fig. $4 \mathrm{a}$ shows a much better image of the subsurface geometries. The stratigraphy is much clearer and even in the central part, where the section crosses the carbonates, it gives some indication of the subsurface structures forming the Gubbio anticline. The section of fig. $3 \mathrm{~b}$ shows good reflections associated with the most reflective horizons of the stratigraphy at about $1 \mathrm{~s}$ and $2 \mathrm{~s}$ (twt). Besides, the section of fig. 4a also shows a very good image of a normal fault, the SWdipping Gubbio normal fault, which downthrows the western limb of the Gubbio anticline (Mirabella et al., 2004). The same structure in the section of fig. $3 \mathrm{~b}$ is not well resolved.

The section of fig. $4 \mathrm{c}$ is a Vibroseis seismic line acquired across the Inner Rigde of the Umbria-Marche Apennines (seismic line S12 in fig. 3). The section was reprocessed to increase 
the signal to noise ratio (Stucchi et al., 2006). Due to the outcropping lithologies, the reprocessing is much more effective in the western part of the section where the Miocene turbidites crop out, than in the in eastern part, where the section crosses the highly deformed carbonated of the Inner Ridge.

\section{Extensional tectonics}

The concept that the Quaternary tectonics of the Umbria-Marche region is dominated by NW-SE trending normal faults was recognised early in the Apennines by field geologists: the SW-dipping Gubbio and Norcia normal faults (fig.1a) are precisely mapped on the old 1:100,000 geological maps, surveyed by Scarsella during the '40s (Servizio Geologico d'Italia, 1941; 1951). However, the subsurface geometry of these faults, their attitude and detachment depth were unknown and could be argued only by geometrical constructions (Menichetti and Minelli, 1991), by the comparison with other regions of extensional tectonics (e.g. Wernicke, 1981) and by pioneer geophysical studies like seismic refraction profiles (Alfano et al., 1982). The first attempt of proposing a regional model, where the extensional tectonics is related to the crustal structure and to the historical seismicity, is due to Lavecchia et al. (1984). The model (fig. 5a) proposes a set of major SW-dipping detachments, affecting the whole crust, with a pronounced staircase trajectory: the extensional Tuscany and western Umbria basins of the Apennines are formed at the hanging-wall of the major faults. The model incorporates the concept of the eastwards migration through time of the extensional deformation, previously proposed by Elter et al. (1975). Ten years later, Lavecchia et al., (1994a; b) (fig. $5 b)$ reproposed and improved their previous model, incorporating the seismological data available at that time into a seismotectonic zoning, which considers both the extensional earthquakes, affecting the Apennine ridge, and the compressional earthquakes along the Adriatic coast (fig. 5b): the extensional detachments invert previous SW-dipping, crustal-scale thrusts.

A completely different style of deformation was proposed by Bally et al. (1986) (fig. 5c). In these profiles the relatively shallow, listric normal faults merge into a slightly West-dipping detachment located at the base of the sedimentary cover. A combination of the two models is proposed by Keller et al. (1994) (fig. 5d), where large, SW-dipping faults affecting the basement are detached at a depth of about $7 \mathrm{~km}$. This model first incorporates the presence of E-dipping, low-angle normal faults: however, the Edipping low-angle normal faults are considered to be antithetic to the SW-dipping master faults.

The detailed subsurface geometry of the single normal faults of the region was mainly derived by extrapolating surface geology observations. In particular, e.g. Menichetti and Minelli (1991) use the geometry of the Gubbio Quaternary basin to deduce the depth of detachment of the Gubbio normal fault.

In general, the greater longitudinal continuity and morphological evidence of the SW dipping normal faults cropping out at the surface supported the idea that the extension was driven by SW-dipping master normal faults, whilst the NE-dipping faults were antithetic to them. However, in the Perugia Mts. area (i.e. west of the high Tiber basin, fig. 1a), the presence of NE-dipping normal faults was early recognised (Dessau, 1962), superposing Miocene turbidites over Triassic Evaporites (Minelli and Menichetti, 1990): the same tectonic contact was drilled by the boreholes Perugia 2 and S. Donato 1 (Anelli et al., 1994). Later on, detailed field mapping of the Perugia Mts. area showed the existence of domino-like NE-dipping extensional structures (Brozzetti, 1995).

After the mid ' $90 \mathrm{~s}$, the availability of industrial seismic data and the CROP-03 crustal seismic profile (Pialli et al., 1998) brought new information about the extensional deformation style. The interpretation of the seismic sections defined the subsurface geometry of the main extensional structures of the area and the mutual relationships between them. Six major ENEdipping extensional detachments were recognised along the CROP-03 section affecting the upper crust of the Italian peninsula from the Tyrrhenian Sea to the main ridge of the Apennines. The easternmost, still active detachment is the Altotiberina normal fault (hereinafter 


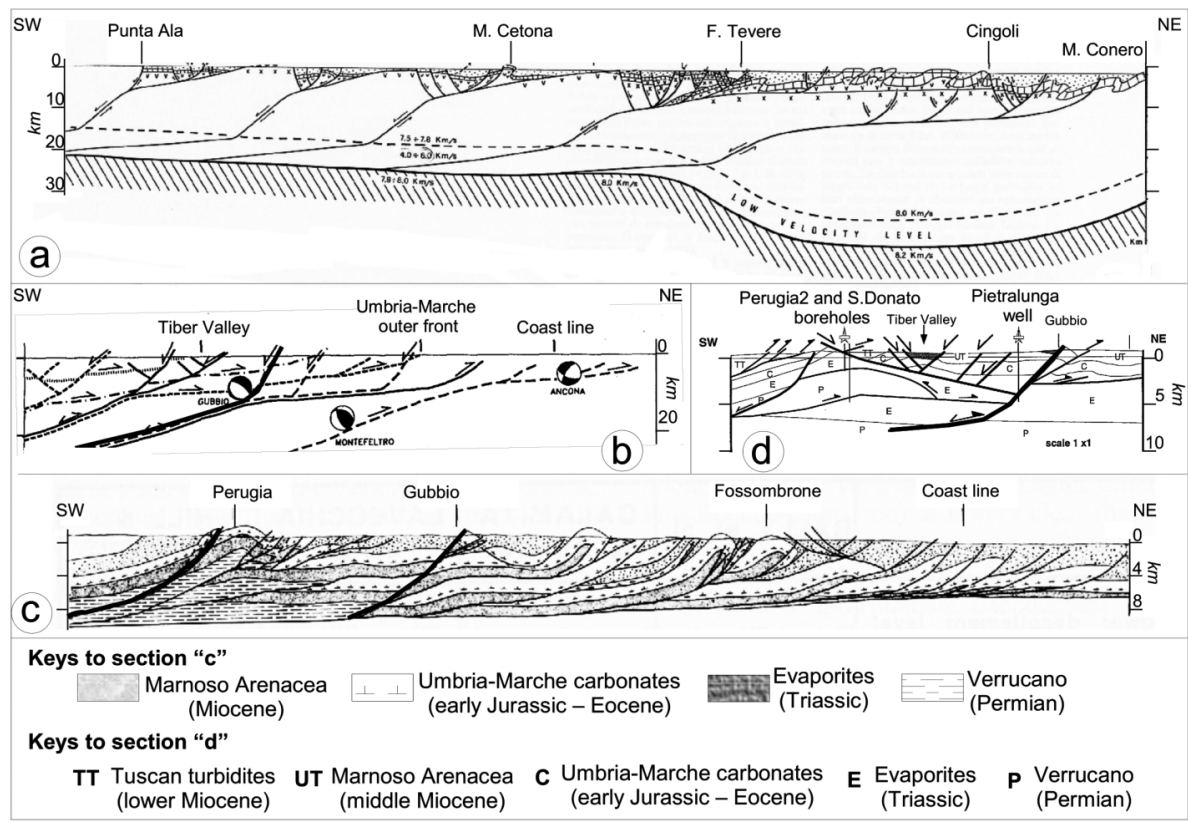

Fig. 5a-d. Subsurface geological reconstructions of the Northern Apennines. a) crustal extension is accommodated by West-dipping detachments (Lavecchia et al., 1984), a model inspired to the «Basin and Range» model; b) the West-dipping master normal faults are interpreted as inverting the older thrusts at depth (Lavecchia et al., 1994b); c) Bally et al. (1986)'s reconstructions based on seismic data and inspired to the Canadian Rockies; d) the East-dipping normal faults drilled by boreholes are interpreted as antithetic to the West-dipping normal faults (Keller et al., 1994). In each section the horizontal scale is equal to the vertical scale.

ATF), which the west-dipping normal faults are antithetic to (Barchi et al., 1995; 1998a; Boncio et al., 1998).

The subsurface extension and attitude of the ATF was subsequently refined by interpreting a wide data-set of seismic reflection profiles (Sections S1 to S12 in fig. 3). On the basis of these data, it was possible to map the ATF for a length of at least $55 \mathrm{~km}$ long along the Tiber Valley and to draw the fault plane down to about 12 km depth (Barchi et al., 1998a; 1999; Boncio et al., 1998; Collettini et al., 2000; Mirabella, 2002; Pauselli et al., 2002).

Boncio et al. (2000) hypothesised the longitudinal extension of ATF (or of other similar Edipping detachments) along a regional extensional system (Etrurian Fault System, fig. 1b), both towards SE and towards NW. Towards the NW, the Etrurian Fault System would be the master fault bordering the western flanks of the Casentino, Mugello, Garfagnana and Lunigiana grabens. Towards the SE, the Etrurian Fault System would extend to the area of Norcia (fig. 1b).

Concerning the north-western extension, NW of the CROP-03 section, the Pieve S. Stefano well (Anelli et al., 1994) drills at least two main extensional contacts (fig. 6, location in fig. 1a). The upper extensional contact is between Upper Oligocene-lower Miocene turbidites (the Tuscan units) and lower Jurassic-early Palaeocene carbonates (the Umbria-Marche limestones) with the consequent elision of more than $1.5 \mathrm{~km}$ of Umbrian turbiditic units (Marnoso Arenacea fm, Miocene).

The main upper contact (at 1268,5m of depth fig. 6) is between the Tuscan units and the calcareous Scaglia (early Palaeocene). A secondary splay of this elision (at 1445,5m of 


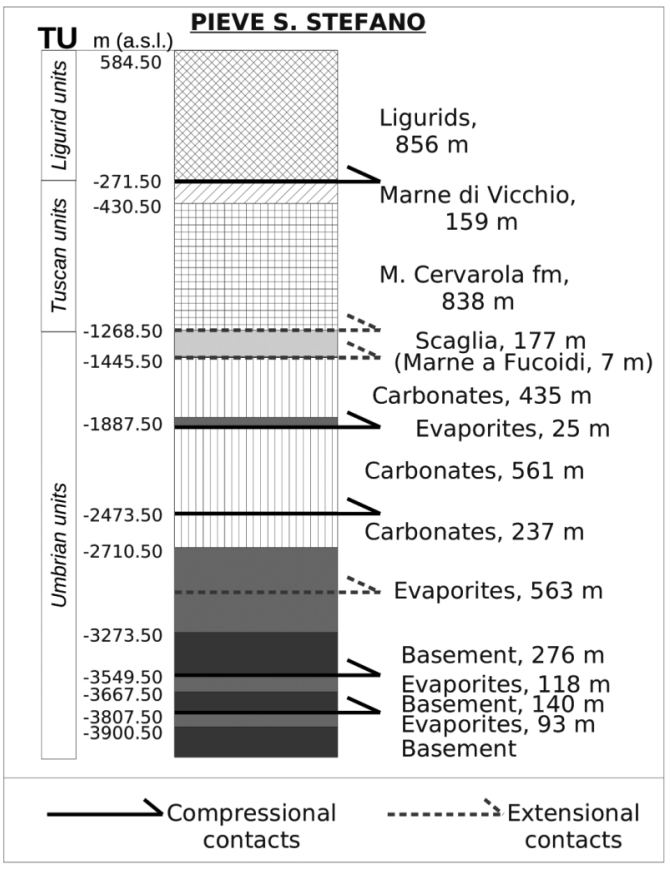

Fig. 6. Stratigraphy and interpretation of the Pieve S. Stefano well log (location in fig. 1a). The Umbrian units are upper Paleozoic - Miocene in age, the Tuscan Units are Oligocene - Miocene, the Ligurian Units are Cretaceous in age.

depth) can also be supposed by the reduced thickness of both the calcareous Scaglia (177m) and the Marne a Fucoidi fm $(7 \mathrm{~m})$ which are usually 350-400 and 50-70 $\mathrm{m}$ thick respectively as shown by both boreholes and outcrops (e.g. Cresta et al., 1989; Anelli et al., 1994; Barchi et al., 1998a).

The second main extensional contact is between 2710 and 3273m within the Evaporites which are $563 \mathrm{~m}$ thick, about one third of their thickness as shown both in other boreholes and in the seismic sections of the area (e.g. Bally et al., 1986; Anelli et al., 1994; Barchi et al., 1998a).

By the correlation of the Pieve S. Stefano well $\log$ with the seismic data in this area, NW of the S. Sepolcro basin, these extensional contacts can be correlated with a north-western splay of the ATF (Mirabella et al., 2006), confirming the idea of a extension of the ATF towards NW. The extension of the ATF towards SE can be reasonably hypothesised, as suggested by Boncio et al., (2000), even if the available seismic data do not image such structure. This could be due to either insufficient seismic energy or to the occurrence of the ATF at depth greater than that investigated by the seismic sections (Mirabella et al., 2008).

The seismic reflection data also image in detail the subsurface geometry of the Gubbio fault (Barchi et al., 1999; Pauselli et al., 2002; Collettini et al., 2003; Mirabella et al., 2004) (fig. 7a). The fault is considered to be active and the detailed characterization of the fault plane geometry is fundamental in order to estimate its seismogenic potential. The fault is characterised by a listric geometry (fig. 4a, 7a), its dip being about $60^{\circ}$ at the surface, about $40^{\circ}$ at intermediate depths (3-4 km) and about $20^{\circ}$ at greater depth, where it negatively inverts a pre-existing thrust. The long-term maximum offset of the Gubbio fault, measured on a key reflector within the Umbria-Marche stratigraphy (Marne a Fucoidi fm, fig. 2) providing a value of about $3 \mathrm{~km}$ (Mirabella et al., 2004).

In the southern part of the study area (in the region of the Colfiorito and Sellano earthquakes, fig. 3), both the seismic data quality and quantity decrease. Only two sections are available (S13 and S14 in fig. 3) which cross the 1997-98 earthquake area. These sections do not image well the normal faults at depth due to the relatively small offsets of these faults (about 500-600 m, Mirabella et al., 2005), and to the fact that they superimpose similar rocks (carbonates and/or evaporites) with low impedance contrast (Stucchi et al., 2006; Mirabella et al., 2008).

\section{Upper crust structure}

In the study area, the industrial seismic reflection profiles are acquired down to about 4-5 $s$ (twt). Based on average interval velocities of the area (fig. 2) compiled by previous authors from borehole data (Bally et al., 1986; Barchi et al., 1998b), these depths correspond to about 12 $\mathrm{km}$. 
The work by Bally et al. (1986) is the first regional study based on extensive study of seismic data concerning the structural style of the area. Their interpretation envisages a thinskinned tectonic model in which the sedimentary cover is completely detached from the underlying basement (fig. 5c) that constantly deepens from the Adriatic below the Apennine ridge from about $6 \mathrm{~km}$ to about $8 \mathrm{~km}$. This structure was based on some reflections visible on the seismic sections and by analogy with the structure of the Canadian Rocky Mountains and was named the «regional monocline». Alternatively, a thick-skinned model was proposed, where at least the upper part of the Basement is involved (Ghisetti et al., 1993; Sage et al., 1991). The model was subsequently refined, using the results of the CROP-03 profile (Barchi et al., 1995; 1998a; b).

In this model, the Apennines underwent less shortening and the sedimentary cover was thinner than in the previous model. As a result, the top of the basement was shallower than in the previous interpretations.

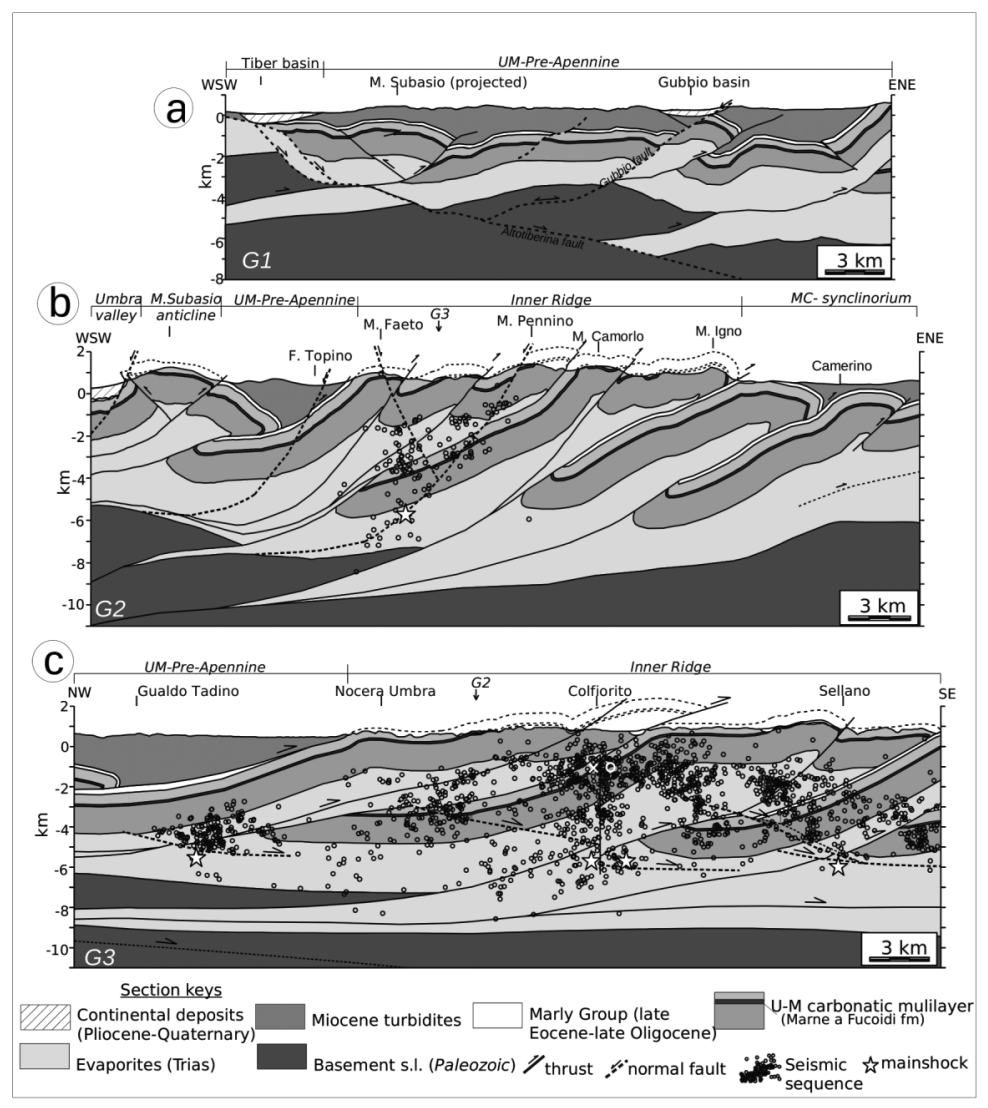

Fig. 7. a) Geological section G1 corresponding to seismic line S8 (location in fig. 3) across the Umbria preApennines; b) Geological section G2 corresponding to seismic line S13 (location in fig. 3, after Mirabella et al., 2008) across the Inner Ridge of the Umbria-Marche Apennines. c) Longitudinal section G3 (location in fig. 3) across the 1997-98 seismic sequence, after Mirabella et al. (2008). The section is constructed by the intersection with three seismic lines (S12, S13 and S14 in fig. 3) and calibrated with surface geology data. See text for details. 


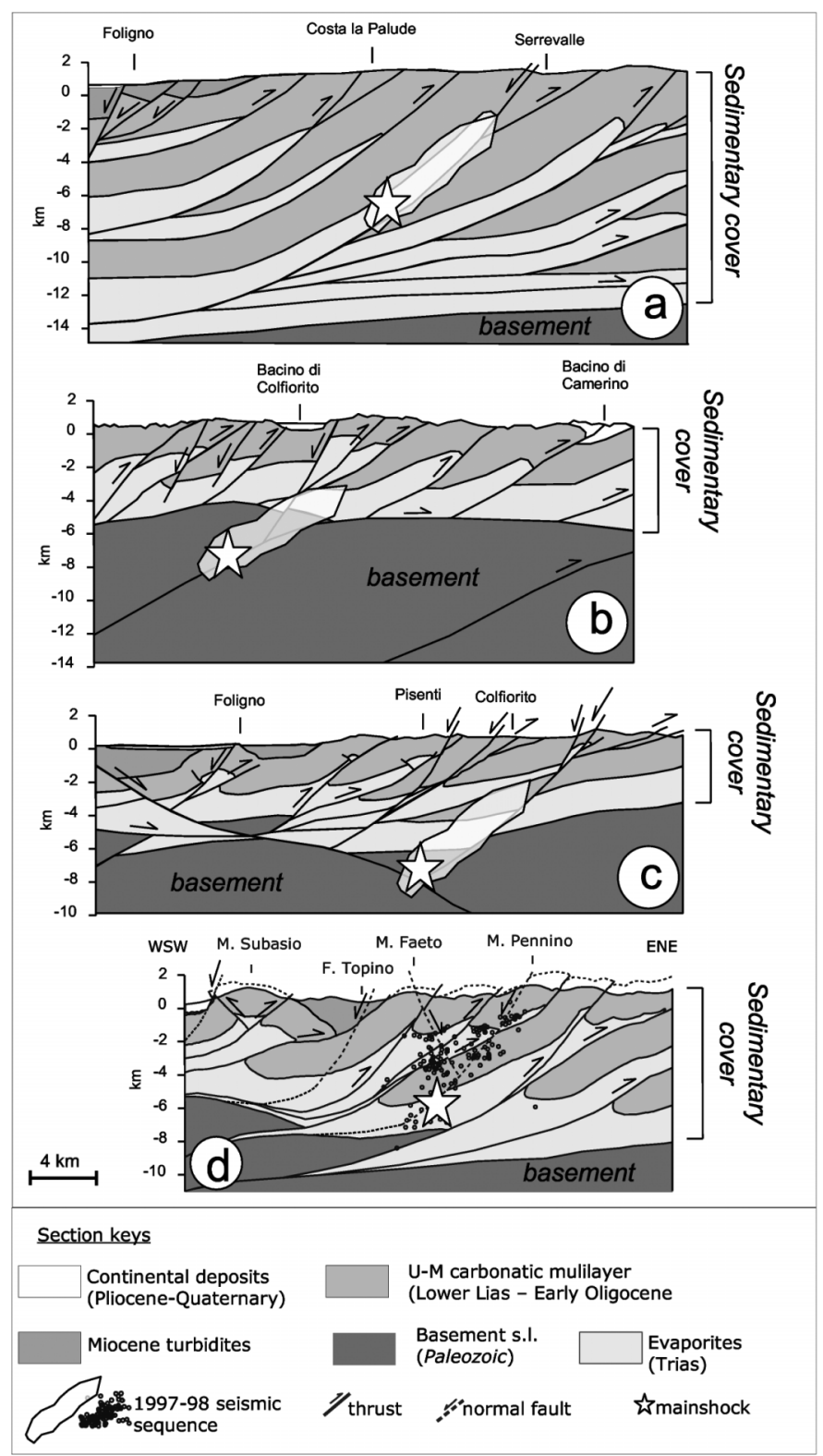

Fig. 8. Relationships between crustal structure and seismicity proposed by different authors. a) Redrawn after Cinti et al. (1999). Cinti et al. (1999) and Meghraoui et al. (1999) have projected the 1997-98 seismic sequence on the section by Bally et al. (1986) and propose extensional inversion of the thrusts. The seismic sequence occur within sedimentary rocks; b) cross-section redrawn after by Calamita et al. (2000) in which the seismic sequence occur mostly within the Basement rocks; c) Redrawn after Boncio and Lavecchia (2000) who propose that the normal faults are antithetic to a low angle-detachment; d) Part of section G2 (figure 7b), redrawn after Mirabella et al. (2008). They propose that the seismic sequence is entirely located within the sedimentary cover and that the mainshocks are located within the Triassic evaporites. 
Other thick-skinned models of the subsurface (Coward et al., 1999; Scisciani and Montefalcone, 2005) interpret the main compressional structures as inverting previous Triassic extensional basins.

The interpretation of the seismic data-set shown in fig. 3 has yielded further information (Barchi et al., 1999; Pauselli et al., 2002; Mirabella et al., 2004). Other improvements came from the reprocessing of the sections S12, S13 and S14 (Mirabella et al., 2008). The interpretation of this data-set suggest the coexistence of both thin- and thick- skinned tectonics. The basement is involved in the compressional structures (fig. 7a,b) in the Umbria-Marche perApennines. Beneath the Umbria-Marche Apennines Inner Ridge, the basement is a gently west dipping surface which deepens from East to West, similar to the «regional monocline» of Bally et al., (1986). The basement steps formed by the compressional structures are such that the top of the basement is shallower (about 5 $\mathrm{km})$ in the western part than in the eastern part (fig. $7 \mathrm{~b}, \mathrm{c}$ ), below the chain (about $9 \mathrm{~km}$ ).

The thrusts which involve the basement are characterised by an arcuate shape with similar geometry as the arcuate shape of the carbonatic ridges at the surface (see fig. 1). This is due to the fact that the main thrusts which involve the basement are detached within the basement top and ramp up to the surface, forming the «Inner» and «Outer» ridges of the Umbria-Marche Apennines. These two anticlinoria have a wavelength of about $20 \mathrm{~km}$, the wavelength being dependent on the depth of the detachment level (Barchi et al., 1998b). The internal structure of the anticlinoria is composed of shorter wavelength structures $(3-5 \mathrm{~km})$ which are detached at higher stratigraphic levels, like the evaporites and the marl horizons within the carbonates (multiple detachment model, Barchi et al., 1998b).

Beside the structural style, the definition of the subsurface tectonic setting has also deep implications on the seismotectonic setting of the region, in particular on geometry of the active faults at depth and on the rocks involved in seismic faulting.

Soon after the 1997-98 Umbria-Marche seismic crisis (e.g. Amato et al., 1998) several authors proposed different reconstructions of the subsurface geology at seismogenic depths. Cinti et al. (1999) and Meghraoui et al. (1999) (fig. 6a, 8a) have projected the 1997-98 seismic sequence on the section drawn by Bally et al. (1986) and interpret the normal faults activated during the Umbria-Marche crises as inverting previous thrusts. The seismic sequence occurs within the sedimentary cover composed of carbonates and levaporites (fig. 8a). Calamita et al. (2000) proposed a different interpretation (fig. 8b) where the compressional structures are formed by two main thrusts crosscutting the entire upper brittle crust from at least $15 \mathrm{~km}$ up to the surface and by secondary structures detached at the base of the sedimentary cover which produce the pattern of anticlines involving the carbonates. In this interpretation, the normal faults activated during 1997-98 invert at depth the main thrusts and the earthquake sequence occurs mainly within the basement rocks.

In the interpretation by Boncio and Lavecchia (2000) the compressional structures involve the basement and branch out towards the surface forming the anticlines which involve the carbonates (fig. 8c). The normal faults activated in 1997-98 are antithetic to an east-dipping extensional detachment and do not reactivate the previous thrusts. The earthquake sequence involves both the basement and the sedimentary cover.

Through the interpretation of the seismic data-set shown in fig. 3, and in particular of the three reprocessed seismic sections S12, S13, S14 it has been suggested that the 1997-98 seismic sequence is entirely located within the sedimentary cover, which is thickened by the previous compressional tectonics (Mirabella et al., 2008). Besides, the mainshocks of the sequence are located within the Triassic Evaporites (fig. $8 d)$. According to the interpretation made, the controlling factor of the seismogenic layer thickness could be a low-velocity layer located at the top of the crystalline basement (Mirabella et al., 2008). This layer (about $2 \mathrm{~km}$ thick) is characterised by a strong inversion of $\mathrm{Vp}$ velocities from about $6.1 \mathrm{~km} / \mathrm{s}$ in the overlying evaporites to about $5.1 \mathrm{~km} / \mathrm{s}$ (see fig. 2).

In the Umbria-Marche area, a general southeastern deepening of the seismicity cut-off depth is commonly observed. Shallower depths 
were recorded for the 1984 Gubbio sequence (Haessler et al., 1988; Collettini et al., 2003), NW of Colfiorito and greater depths were recorded for the Norcia sequence in 1979 (Deschamps et al., 1984), SE of Colfiorito. The available subsurface data show a similar decrease of the top of the basement depth along the same trend. The deepening of the basement from NW to SE is mainly due to the arc-shaped geometry of the compressional structures, hence their trend is about NW-SE in the northwestern part (from Città di Castello to Perugia) and about N-S in the south-eastern part (from Gualdo Tadino to Norcia) (fig. 1a).

On the other hand, the extensional structures, to which most of the upper crust seismicity is related, are aligned along a NW-SE trend. This setting is such that the extensional structures intersect the top of the basement at progressively increasing depths from NW to SE, depending on which basement step they encounter (fig. 7c). Correspondingly, from NW to $\mathrm{SE}$, the cut-off of the seismicity is progressively deeper, from 5-6 km in the Gubbio area (Haessler et al., 1988) to $10-12 \mathrm{~km}$ in the Norcia area (Deschamps et al., 1984).

\section{Conclusions}

The availability of industrial seismic lines in the Umbria-Marche area has yielded previously unknown information on the subsurface structures. Before subsurface data were available, both the compressional and extensional deformation styles resulted from extrapolation at depth of surface data and from analogies with other parts of the world. The main innovations brought by the seismic lines and boreholes can be summarised as follows:

The deformation style of the UmbriaMarche region is characterised by a thickskinned tectonics in which the upper part of the basement is involved in the compressional structures which form the Umbria-Marche Apennines.

The tectonic setting inherited by the compressional structures also affects the crustal thickness in which the shallow extensional seismicity occurs. In the Umbria-Marche Apen- nines the moderate earthquakes occur within sedimentary rocks and the mainshocks are located within the Triassic evaporites.

The extension is dominated by crustal-scale low angle detachments dipping towards ENE to which the SW-dipping normal faults are antithetic.

The easternmost extensional detachment is the Altotiberina normal fault which borders the Tiber Valley for at least $55 \mathrm{~km}$ of longitudinal length.

The seismic data allow to describe both the subsurface geometry of the active faults and to map their longitudinal continuity and long-term offset distribution. In the Umbria-Marche region, the SW-dipping normal faults as characterised by a decrease of the dip with depth.

\section{Acknowledgements}

We thank V. Scisciani and two anonymous reviewers for their comments and suggestions. We thank ENI S.p.A for providing the seismic reflection data. This work was financed by GNDT 2005 and DPC-INGV-2005-07 fundings, grants to M.R. Barchi.

\section{REFERENCES}

Alfano, A., F. Decandia, G. Lavecchia, G. Pialli, G. Biella, A. LozeJ and B. Treves (1982): Profilo Piombino-Ancona: dati geofisici ed interpretazione geologica, Boll. Soc. Geol. It., 101, 247-258.

Амато, A., and «Rete Sismica Nazionale working group» (2006): Il sistema di monitoraggio sismico in Italia, (XXV GNGTS, Roma, November 28-30), 82-83.

Амато, A. et al. (1998): The 1997 Umbria-Marche, Italy, earthquake sequence: a first look at the main shocks and aftershocks, Geophys. Res. Lett., 25, 15, 2861-2864.

Anelli, L., M. Gorza, M. Pieri and M. Riva (1994): Subsurface well data in the Northern Apennines (Italy), Mem. Soc. Geol. It., 48, 461-471.

Bally, A., L. Burbi, C. Cooper and R. Ghelardoni (1986): Balanced sections and seismic reflection profiles across the Central Apennines, Mem. Soc. Geol. It., 35, 257-310.

Barchi, M.R., A. De Feyter, M. Magnani, G. Minelli, G. PiALli and B.M. SOTERA (1998a): Extensional tectonics in the Northern Apennines (Italy): evidence from the CROP03 deep seismic reflection line, Mem. Soc. Geol. It., 52, 528-538.

Barchi M.R., A. De Feyter, M.B. Magnani, G. Minelli, G. Pialli and B.M. Sotera (1998b): The structural 
style of the Umbria-Marche fold and thrust belt, Mem. Soc. Geol. It., 52, 557-578.

Barchi, M.R., A. Landuzzi, G. Minelli and G. Pialli (2001): Outer northern Apeninnes, in Anatomy of an Orogen: the Apennines and Adjacent Mediterranean Basins, edited by G. VAI and I. MARTINI, pp. 215-254. (Kluwer Academic Publishers, Great Britain).

Barchi, M.R., M. Magnani, G. Minelli, G. Pialli and B. SOTERA (1995): Osservazioni geofisiche sul basamento della regione umbro-marchigiana, Atti GNGTS 14th Conference, 2, 709-720.

Barchi, M.R., S. Paolacci, C. Pauselli, G. Pialli and S. MERLINI (1999): Geometria delle deformazioni estensionali recenti nel bacino dell'Alta Val Tiberina fra S. Giustino Umbro e Perugia: evidenze geofisiche e considerazioni geologiche, Boll. Soc. Geol. It., 118, 617-625.

Barchi, M.R., C. Pauselli, C. Chiarabba, R. Di Stefano and C. FEDERICO (2006): Crustal structure, tectonic evolution and seismogenesis in the Northern Apennines (Italy), Bollettino di Geofisica Teorica ed Applicata, 47 (2), 249-270.

Boncio, P. and G. LAVECCHIA (2000): A geological model for the Colfiorito earthquakes (September-October 1997, central Italy), Journal of Seismology, 4, 345-356.

Boncio, P., F. BRozzetTI and G. LAVECCHIA (2000): Architecture and seismotectonics of a regional Low-Angle Normal Fault Zone in Central Italy, Tectonics, 19, 1038-1055.

Boncio, P., F. Ponziani, F. Brozzetti, M.R. Barchi, G. LAVECCHIA and G. PiALLi (1998): Seismicity and extensional tectonics in the Northern Umbria-Marche Apennines, Mem. Soc. Geol. It., 52, 539-555.

Boschi, E., E. Guidoboni, G. Ferrari, D. Mariotti, G. VAlensise and P. Gasperini (2000): Catalogue of strong italian earthquakes from 461 b.c. To 1997, Annali di Geofisica, 43, 609-868.

BrozzetTI, F. (1995): Stile strutturale della tettonica distensiva nell'Umbria occidentale: l'esempio dei Massicci Mesozoici Perugini, Studi Geologici Camerti, (vol. spec. 1995/1), 105-119.

Calamita, F., M. Coltorti, D. Piccinini, P. Pierantoni, A. PizZI, M. Ripepe, V. Scisciani and E. Turco (2000): Quaternary faults and seismicity in the UmbroMarchean Apennines (Central Italy): evidence from the 1997 Colfiorito earthquake, J. Geodyn, 29, 245-264.

Chiarabba, C., L. Jovane and R. Di Stefano (2005): A new view of the Italian seismicity using 20 years of instrumental recordings, Tectonophysics, 395, 251-268.

Chiaraluce, L., M.R. Barchi, C. Collettini, F. MirabelLA and S. PUCCI (2005): Connecting seismically active normal faults with Quaternary geological structures in a complex extensional environment: the Colfiorito 1997 case history (northern Apennines, Italy), Tectonics, 24, TC1002, doi: 10.1029/2004 TC001627.

Chiaraluce, L., W. Ellsworth, C. Chiarabba and M. Cocco (2003): Imaging the complexity of an active complex normal fault system: the 1997 Colfiorito (central Italy) case study, J. Geophys. Res., 108/B6, 2294.

Ciaccio, M., M.R. Barchi, C. Chiarabba, F. Mirabella and E. STUCCHI (2005): Seismological, geological and geophysical constraints for the Gualdo Tadino fault, Umbria-Marche Apennines (Central Italy), Tectonophysics, 406 (3/4), 233-247.
Cinti, F., L. Cucci, F. Marra and P. Montone (1999): The 1997 Umbria-Marche (Italy) earthquake sequence: relationship between ground deformation and seismogenic structure, Geophys. Res. Lett., 26 (7), 895-898.

Collettini, C., M.R. Barchi, L. Chiaraluce, F. MirabelLA and S. PuCCI (2003): The Gubbio fault: can different methods give pictures of the same object?, J. Geodyn., 36, 51-66, doi: 10.1016/S0264-3707(03)00038-3.

Collettini, C., M.R. Barchi, C. Pauselli, C. Federico and G. Pialli (2000): Seismic expression of active extensional faults in Northern Umbria (Central Italy), $J$. Geodyn, 29, 309-321.

Coward, M., M. DeDonatis, S. Mazzoli, W. Paltrinieri and F. WeZEL (1999): Frontal part of the northern Apennines fold and thrust belt in the Romagna-Marche arc (Italy): shallow and deep structural styles, Tectonics, 18 (3), 559-574.

Cresta, S., S. Monechi and G. PARISI (1989): Stratigrafia del mesozoico e cenozoico nell'area umbro-marchigiana. Itinerari geologici sull'Appennino umbro-marchigiano (Italia), Mem. Descrittive della Carta Geologica d'Italia, $39,1-182$.

De Franco, R., F. Ponziani, G. Biella, G. Boniolo, G. Caielli, A. Corsi, M. Maistrello and A. Morrone (1998): Dss-war experiment in support of the Crop03 project, Mem. Soc. Geol. Ital., 52, 67-90.

Deschamps, A., G. InNACCONE and R. Scarpa (1984). The umbrian earthquake (Italy) of 19 september 1979, Annales Geophysicae, 2 (1), 29-36.

Dessau, G. (1962): Geologia del M. Malbe nel quadro dei Massicci Mesozoici del perugino, Boll. Soc. Geol. It., 81, 225-315.

Elter, P., G. Giglia, M. Tongiorgi and L. Trevisan (1975): Tensional and compressional areas in the recent (Tortonian to Present) evolution of North Apennines, Bollettino di Geofisica Teorica ed Applicata, 17, 3-18.

Ghisetti, F., M.R. Barchi, A.W. Bally, I. Moretti and L. VEZZANI (1993): Conflicting balanced structural sections across the central Apennines (Italy): problems and implications, in Generation, accumulation and production of europe's hydrocarbons, edited by SPENCER. (Special publication of the european association of petroleum geoscientists, Springer-Verlag, Berlin Heidelberg).

Haessler, H., R. Gaulon, L. Rivera, R. Console, M. Frogneux, G. Gasparini, L. Martel, G. Patau, M. SiCILIANO and A. Cisternas (1988): The Perugia (Italy) earthquake of 29 april 1984: a microearthquake survey, BSSA, 78 (6), 1948-1964.

Keller, J., G. Minelli and G. Pialli (1994): Anatomy of a late orogenic extension: the Northern Apeninnes case, Tectonophysics, 238, 275-294.

Lavecchia, G., M.R. BARChi, F. Brozzetti and M. Menichetti (1994b): Sismicità e tettonica nell'area umbro-marchigiana, Boll. Soc. Geol. It., 113, 483-500.

Lavecchia, G., F. Brozzetti, M.R. BARChi, J. Keller and M. Menichetti (1994a): Seismotectonic zoning in east-central Italy deduced from the analysis of the Neogene to present deformations and related stress fields, Geological Society of America Bulletin, 106, 11071120.

Lavecchia, G., G. Minelli and G. Pialli (1984): L’Appennino Umbro-Marchigiano: tettonica distensiva ed 
ipotesi di sismogenesi, Boll. Soc. Geol. It., 103, 467476.

Lazzarotto, A., M. Aldinucci, S. Cirilli, A. Costantini, F. Decandia, E. Pandeli, F. Sandrelli and A. Spina (2003): Stratigraphic correlation of the Upper Palaeozoic-Triassic successions in southern Tuscany, Italy, Boll. Soc. Geol. It., vol. spec. 2, 25-35.

LotTI, B. (1926). Descrizione geologica dell'umbria, Mem. descrittive della Carta Geologica d'Italia, 21, 1-320.

Martinis, B. and M. PIERI (1964): Alcune notizie sulla formazione evaporitica dell'Italia centrale e meridionale, Mem. Soc. Geol. It., 4, 649-678.

Meghraoui, M., V. Bosi and T. Camelbeeck (1999): Fault fragment control in the 1997 Umbria-Marche, central Italy, earthquake sequence, Geophys. Res. Lett., 26 (8), 1069-1072.

Menichetti, M. and G. Pialli (1986): Geologia strutturale del Preappennino umbro tra i Monti di Gubbio e la catena del M.Petrano-M.Cucco (Appennino UmbroMarchigiano), Mem. Soc. Geol. It., 35, 371-388.

Menichetti, M. and G. Minelli (1991): Extensional tectonics and seismogenesis in Umbria (Central Italy): the Gubbio Area, Boll. Soc. Geol. It., 110, 857-880.

MerLA, G. (1951): Geologia dell'Appennino settentrionale, Boll. Soc. Geol. It., 70 (1), 29-142.

Minelli, G. and M. Menichetti (1990): Tectonic evolution of the Perugia massifs area (central Italy), Boll. Soc. Geol. It., 109 (5), 445-453.

Mirabella, F. (2002): Seismogenesis of the UmbriaMarche region (Central Italy): geometry and kinematics of the active faults and mechanical behaviour of the involved rocks, (University of Perugia, Italy), PhD thesis.

Mirabella, F., M.R. BARChi, A. Lupattelli and S. RogleDI (2006): Seismic data in the San Sepolcro and Casentino Quaternary basins (Northern Apennines): inferences on the geometry of the associated extensional system, XXV GNGTS, Roma, November 28-30, 314-316.

Mirabella, F., M.R. Barchi, A. Lupattelli, E. Stucchi and M.G. CIACCIO (2008): Insights on the seismogenic layer thickness from the upper crust structure of the Umbria-Marche Apennines (Central Italy), Tectonics, 27, TC1010: doi: 10.1029/2007TC002134.

Mirabella, F., V. Boccali and M.R. Barchi (2005): Segmentation and interaction of normal faults within the Colfiorito fault system (Central Italy), in Deformation Mechanisms, Rheology and Tectonics: from Minerals to the Lithosphere, edited by D. GAPAIS, J. BRUN, and P. CobBold, pp. 25-36, Geological Society Special Publication, 243, London.

Mirabella, F., M.G. Ciaccio, M.R. Barchi and S. MerliNI (2004): The Gubbio normal fault (Central Italy): geometry, displacement distribution and tectonic evo- lution, J. Struct. Geol., 26, 2233-2249, doi: 10.1016/j.jsg.2004.06.009.

PATACCA, E., and P. SCANDONE (2001): Late thrust propagation and sedimentary response in the thrust-beltf oredeep system of the southern Apennines (Pliocene- Pleistocene), in Anatomy of an Orogen: the Apennines and Adjacent Mediterranean Basins, edited by G. VAI and I. MartinI, (Kluwer Acad., Norwell, Mass), pp. 441-454.

PAuselli, C., R. MARChesi and M.R. BARChI (2002): Seismic image of the compressional and extensional structures in the Gubbio area (Umbrian-Pre Apennines), Boll. Soc. Geol. It., vol. spec. 1, 263-272.

Pialli, G., M.R. BARCHI and G. Minelli (1998): Results of the crop03 deep seismic reflection profile, Mem. Soc. Geol. It., 52, 654.

Piccinini, D., M. Cattaneo, C. Chiarabba, L. Chiaraluce, M. De Martin, M. Di Bona, M. Moretti, G. Selvaggi, P. Augliera, D. Spallarossa, G. Ferretti, A. Michelini, A. Govoni, P. Di Bartolomeo, M. RoMANELLI and J. FABBRI (2003): A microseismic study in a low seismicity area of Italy: the Città di Castello 2000-2001 experiment, Annals of Geophysics, 46, 6, 1315-1324.

Ponziani, F., R. De Franco, G. Minelli, G. Biella, C. FEDERICO and G. PiAlLi (1995): Crustal shortening and duplication of the Moho in the Northern Apennines: a view from seismic refraction data, Tectonophysics, 252, 391-418.

Sage, L., A. Mosconi, I. Moretti, E. Riva and F. Roure (1991): Cross sections balancing in the Central Apennines; an application of LOCACE, AAPG Bulletin, 75, 832-844.

ScARSELla, F. (1951): Un aggruppamento di pieghe dell'Appennino umbro-marchigiano, Boll. Servizio Geologico d'Italia, 73, 309-320.

Scisciani, V. and R. Montefalcone (2005): Evoluzione neogenico-quaternaria del fronte della catena centroappenninica: vincoli dal bilanciamento sequenziale di una sezione geologica regionale, Boll. Soc. Geol. It., 124, 3, 579-599.

Servizio Geologico d'Italia (1941): Foglio 132 (Norcia) della carta geologica d'Italia, scala 1:100.000. Note illustrative.

Servizio Geologico d'Italia (1951): Foglio 116 (Gubbio) della carta geologica d'Italia, scala 1:100.000. Note illustrative.

Stucchi, E., F. Mirabella and M.G. Ciaccio (2006): Comparison between reprocessed seismic profiles seismologic and geologic data: a case study of the Colfiorito earthquake area, Geophysics, 71(2), B29-B40.

WERNICKE, B. (1981): Low angle normal faults in the basin and Range Province: Nappe tectonics in an extending orogen, Nature, 291, 645-648. 